\section{Immunity of Aphids to Insect Parasites}

A study has been made of the susceptibility to, or immunity from, parasitism which certain aphis exhibit towards the insect Monoctonus paludum Marshall (Hymenoptera, Braconidae). Starý ${ }^{1}$, in a recent revision of the European species of Monoctonus, identifies $M$. paludum with $M$. crepidis Haliday, which has been recorded from various aphid hosts on plants related to lettuce. The present account is concerned only with the association between the parasite and aphids which occur on lettuce, and it has been found that although the parasite will readily oviposit into the five species of lettuce aphids which have been studied, successful development of the parasite can only occur in one of these species.

During oviposition the female parasite lays a single egg, with precision, into the fused thoracic ganglia of each aphid, and it has been shown ${ }^{2}$ that the parasite will readily attack the following species of aphids occurring on lettuce: Nasonovia ribis-nigri (Mosley), Macrosiphum euphorbiae (Thos.), Myzus persicae (Sulz.), Aulacorthum solani (Kalt.), Aulacorthum circumflexum (Buckton).

However, of these five species of aphids only $N$. ribis-nigri supports successful development of the parasite's eggs and, in order to determine the reasons for failure of parasite development in the other species, sections and dissections of these aphids have been carried out at various time-intervals after attack.

A full report of this work will be given in a subsequent paper. The interesting facts which emerge at the present time are that segmentation of the parasite egg begins normally in all the aphids studied but that, in the species Macrosiphum euphorbiae, Myzus persicae and Aulacorthum solani, degenerative changes then occur which result in the shrinkage of the parasite tissues and their subsequent disappearance at a later stage.

In the species Aulacorthum circumflexum, however, a different form of immunity reaction occurs. This reaction is contrary to the contention of Flanders ${ }^{3}$, who stated that cellular or phagocytic immunity does not occur in aphids because the number of blood cells is relatively few, for, in this species of aphid, the development of the parasite is arrested by the secretion, around it, of a capsule formed by certain of the host's blood cells. This capsule differs from the

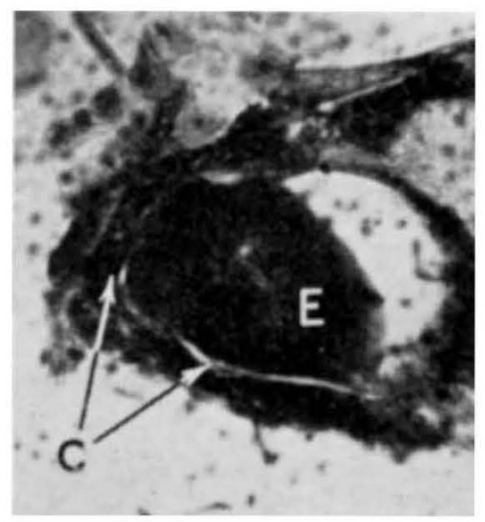

Fig. 1. Section through part of the thoracic nerve ganglia of Aulacorthum circumflexum, $24 \mathrm{hr}$. after attack by Monoctonus paludum. The capsule $(C)$ is beginning to form around the parasite embryo: $(E)$, which lies in a space in the nervous tissue
of the host relatively thick capsules described by Salt ${ }^{4-8}$ in a variety of different insect species as a result of artificial injection of eggs and larvæ of the parasite Nemeritis (Hym. Ichneumonidae) but resembles more the thin, brown capsules described by Schneider ${ }^{7}$ in tho syrphid Epistrophe balteata as a defence against the ichneumon Diplazon. The appearance of the capsule in $A$. circumflexum during its process of formation is shown in Fig. 1.

\section{C. Griffiths}

Department of Zoology,

University of Durham, King's College,

Newcastle upon Tyne.

${ }^{1}$ Starý, P., Acta Soc, Ent. Cecho., 56 (3), 237 (1959). ${ }^{2}$ Griffiths, D. C., Bull. Ent. Res. (in the press).

${ }^{3}$ Flanders, S. E., J. Econ. Ent., 27 (4), 861 (1934).

- Salt, G., Proc. Roy. Soc., B, 144, 380 (1955).

${ }^{5}$ Salt, G., Proc. Roy. Soc., B, 146, 93 (1958).

- Salt, G., Proc. Roy. Soc., B, 147, 167 (1957).

"Schncider, F. von, Vjschr. naturf. Ges. Zurich, 95, 22 (1950).

\section{Function of the Corpus Allatum in 'Dauer-pupa' of the Silkworm, Bombyx mori}

RECENTLY it was reported ${ }^{1}$ than when the corpora allata in the Eri silkworm pupæ were transplanted into artificially diapausing pupe which were obtained by removing their brains at carly pupal time, the diapausing pupæ were induced to emerge in 25 days after the implantation. On the contrary, when the corpora allata derived from the fourth, the fifth instar larvæ or moths of the same insect were transplanted into the artificially diapausing pupæ of the Eri silkworm, most operated animals entered the second pupal instar several weeks after transplantation. The same results were obtained in an experiment on the Cecropia silkworm ${ }^{2}$. When the corpora allata from the Cecropia moths were transplanted into the diapausing pupæ of Hyalophora cecropia, the operated insects became the second pups.

My co-worker and I have shown ${ }^{3}$ that in Bombyx mori each corpus allatum removed from the fourth, the fifth instar larvæ, pupæ and moths respectively had a function which brought about imaginal development probably through the prothoracic gland in 'Dauer-pupæ'.

It is not known, however, whether the corpus allatum in 'Dauer-pupa' of the silkworm, Bombyx mori, has the same function in relation to imaginal differentiation as corpus allatum in normal larva, pupa and moth.

In this communication a function of the corpus allatum in the 'Dauer-pupa' of the silkworm, Bombyx mori, is revealed.

So-called 'Dauer-pupæ' of an $F_{1}$, hybrid between two varieties, J.122 and $C .115$, which had been obtained by extirpating the brain immediately after pupation and did not show any sign of imaginal differentiation for 45 days at $25^{\circ} \mathrm{C}$. after pupation, were used as recipients of the corpora allata which were removed from 'Dauer-pupx' of 45 days old as grafts.

As shown in Table 1, of 20 'Dauer-pupæ' grafted with 3 pairs of corpora allate dorivod from the 'Dauer-pupe', 11 recipients became moths 17-24 days after operation, but the other 4 animals survived 